\title{
Fear of Robots and Life Satisfaction
}

\author{
Tim Hinks ${ }^{1}$
}

Accepted: 26 February 2020 / Published online: 17 March 2020

(c) The Author(s) 2020

\begin{abstract}
The use of robots and in particular next-generation robots in the production of goods and services is increasing. What impact robots are having on people's quality of life, including workers, is as yet under-explored. This paper provides initial findings examining whether fear of robots is correlated with one aspect of quality of life: life satisfaction. After controlling for individual effects and country effects and using both standard ordinary least squares and a linear multilevel regression model, we find fear of robots correlates with lower reported life satisfaction. There are differences in the fear of robots and life satisfaction by age group, by how long countries have been members of the European Union and by whether we control for attitudes towards other things. We call for more research into attitudes towards technology and new technologies in particular, how these impact on current life satisfaction and other aspects of quality of life and to think more about how technological change and people's attitudes towards these can be more aligned.
\end{abstract}

Keywords Technology $\cdot$ Life satisfaction $\cdot$ Europe $\cdot$ Fear of robots

JEL Classification I310 $\cdot \mathrm{C} 210 \cdot \mathrm{O} 330$

\section{Introduction}

Empirical research into what causes and correlates with an individual's life satisfaction has become widespread now in the social sciences and economics literature. Studies have found that absolute income and relative income both correlates with life and job satisfaction, with people's satisfaction levels rising more with relative income increases (e.g. [15, $23,60])$. People who experience unemployment report lower life satisfaction with evidence showing that this experience leaves a permanent scar on their life satisfaction (e.g. [16, 46, 63]). The importance of relationships with family and friends in a person's life satisfaction is confirmed in the works of Cooper et al. [17], Demir et al. [21], Demir and Weitekamp [22] and Diener and Seligman [19]. The importance that the quality of governance and of economic and social institutions and norms have on life satisfaction has also been highlighted $[7,57]$.

Tim Hinks

timothy.hinks@uwe.ac.uk

1 Bristol Centre of Economics and Finance, University of the West of England, Bristol BS16 1QY, UK
A relatively under explored area of research though is what effect new technologies have on life satisfaction. This is surprising given that it is accepted in economics that technological change is one of the driving forces behind previous industrial revolutions which have had profound effects on labour markets and on populations in general. Technology and technological advancement is generally agreed to be skill-biased, resulting in an increase in demand for skilled workers and a decline in demand for unskilled workers [25]. Keynes writing in 1930 argued that technological unemployment would result "due to our discovery of means of economizing the use of labor outrunning the pace at which we can find new uses for labor". ${ }^{1}$ This type of unemployment is an inevitable part of the technologically-driven, creative destruction process that Schumpeter wrote of and that forms part of Kondratieff's long waves of economic growth. ${ }^{2}$ It is not unreasonable to hypothesize then, that technological change is, at least initially, likely to adversely

\footnotetext{
${ }^{1}$ Keynes, J.M. 1930. Economic Possibilities for our Grandchildren, accessed October 10, 2018, http://www.econ.yale.edu/smith/econ116 a/keynes1.pdf.

2 Technology as a component of growth is something [52] labels Schumpeterian growth. By way of an introduction to creative destruction and to Kondratieff growth cycles see Batty [5].
} 
impact many people's life satisfaction directly by making many unemployed. It is also possible that even if people are not directly impacted by technological change, that they are threatened by such change and that this impacts on their life satisfaction. Today, with the advent of the so called 4th industrial revolution or I4.0, the relationship between people and technology is again of interest to researchers.

Recent research into the impact of technology on society has focused on the impact of robots and in the rise in use of next-generation robots. These robots can work alongside workers and are more flexible in the production process often being able to perform multiple tasks rather than just a single task. According to Kumar et al. [43] "I4.0 relies heavily on robotic agents which need to evolve and perform the main operations in the smart manufacturing environment and which are solicited to communicate with human operators, customers, or with diverse distributed partners". This highlights the closer relationship between robots and people in the production process both physically but also for the first time mentally as robots continue to evolve. Many mainstream and nonmainstream economists are predicting that next-generation robots will create a new kind of labour market, one that will be very different to the labour market in the post- $2 \mathrm{WW}$ period.

Autor et al. [4] argue that the current wave of technology, including next-generation robots, will mean the hollowing out of routine-based middle-income jobs and the polarisation of the labour force, something that Goos and Manning [36] find is happening in the UK and has been re-enforced recently by the work of Frey and Osborne [31] and Acemoglu and Restrepo [1] in the US. A number of researchers have also suggested that the rate of robots expansion will continue to and even speed up the lower wage share of output. This has implications for income inequality and the economic bargaining power of workers $[12,24,45,53]$. Whilst a consensus is forming on the impact robots could have on people's livelihoods there is also the frequently heard counter-argument that new jobs will be created and new products will be produced. Robots will also allow people to focus on aspects of jobs that they are better at, that they may prefer and would allow an extension to their working lives [2]. At the heart of the debate is the substitutability between workers and capital. Next generation robots are likely to be better in many unskilled, semi-skilled and even skilled aspects of jobs. This will ultimately mean that workers are more vulnerable to losing their current jobs as they perform fewer tasks in the production process. ${ }^{34}$ There is less research on the impact robotics has on people's behaviour. Papers by Frey et al. [32] and Anelli et al. [3] focus on voting behaviours of people from regions in the US, Europe and the UK respectively that are adversely affected by robotic automation. They find evidence that these regions are more likely to vote for populist leaders. Gallego et al. [34] also find some evidence that automation leads to something of a polarisation in voting patterns of those who benefit from compueterization and those who 'lose-out' to computerization.

Regarding the relationship between new technologies and well-being, recent findings focus on social-media platforms. Presently there remains some dispute as to whether using social media and frequency of using social media is positively or negatively associated with people's well-being (e.g. $[6,13$, $18,54])$. Other research has asked what correlates with people's perceptions of robots and experiences of robots. Dekker et al. [20] find that having a fear of robots declines with the quality of occupation someone has, the years of study and whether someone has used a robot at work. Their multilevel analysis also suggests, but not conclusively, that "economic and institutional conditions matter to some extent for understanding country-level differences in the fear of robots at work" (ibid, p 553). Giuntella and Wang [37] find some evidence that exposure to robots in the workplace in China increases the likelihood of strikes. Hudson et al. [44] use the Eurobarometer 82.4 (2014) survey and find that as people age they become steadily more uncomfortable with having a robot provide services and companionship to elderly or infirm people. This is at odds with Taipale et al. [61] who use Eurobarometer data from a 2012 survey and find that use of robots for caring was supported more by pensioners.

\footnotetext{
3 The prediction of consistently lower average working hours over time due to rising productivity is hardly new with John Maynard Keynes in his 1930 lecture titled Economic Possibilities for our Grandchildren arguing that by the 1970s the workers in the UK would be working a 15-h week. Keynes saw this as a good thing driven by innovation and technology that increases productivity and economic growth. Recent examples of workers negotiating lower working hours to reduce the wage bill and retain employment is seen in Germany and there is a ground swell movement arguing for a 4-day working week in the UK with trials underway.

${ }^{4}$ Another important question raised concerns the ownership of robots and who gains the value these robots add. Freeman [30] makes the simple argument that if workers are to benefit from new technologies that substitute for their skills then they need to own or at least part-own this technology. If the technology is not owned by the worker then they will be worse off, possible working for lower wages and having to work longer hours. One obvious result of this would be increasing inequality. This raises a host of questions to do with maintaining and improving the quality of lives of people, whether work in any way increases the quality of life of people apart from simply selling one's labour, what kind of jobs people will do or want to do in the future and what impact this will have on different form of inequality (income, wealth, opportunity, expectations).
} 
As yet no studies have directly asked what impact perceptions of robots have on the quality of life of people or on the different aspects of the quality of life of people. This paper is the first to explore this question by analysing peoples' perceptions of robots and in particular whether their fear of robots is connected to one aspect of quality of life: namely life satisfaction. We find evidence that people who fear robots report significantly lower life satisfaction scores. The same is found for workers. We also find evidence that once we control for other negative views at the individual level that whilst fear of robots remains a significant correlate of lower life satisfaction that the size of the coefficient declines but remains sizeable and significant in western and northern European countries.

The article is structured as follows. The next section will discuss the data used, the variables of interest and the basic econometric model that is used. Section 3 will report the results which is followed by robustness checks in which we adopt a multi-level approach that models country-level characteristics that are expected to impact on life satisfaction. Section 5 offers a discussion of the results with Sect. 6 providing a number of limitations of the study. We finish with a conclusion.

\section{Data and Variables}

We use data from Eurobarometer 82.4 (2014) survey in this paper, conducted in November and December 2014 on behalf of the European Commission. This survey was the first follow-up study to the Eurobarometer survey Public Attitudes towards Robots conducted in 2012. For 25 of the 28 member states approximately 1000 individuals were interviewed over the age of 15 , with the smaller states of Cyprus, Luxembourg and Malta interviewing approximately 500 people. The sample design applied in all countries is a multi-stage, random (probability) one. In each country, a number of sampling points was drawn with probability proportional to population size (for a total coverage of the country) and to population density. Respondents' opinions were collected regarding their awareness of, usage of, and attitude towards autonomous systems including robots, driverless cars, and civil drones. In this paper we are interested only in questions that relate directly to robots. ${ }^{5}$

Life satisfaction is captured in the survey by the question "On the whole, are you very satisfied $=1$, fairly satisfied $=2$, not very satisfied $=3$ or not at all satisfied $=4$ with the life you lead?". After recoding the answers so higher life satisfaction was given a higher value the average life satisfaction reported from our sample was 3.01 across all countries,

\footnotetext{
${ }^{5}$ For further details of the methodology and sampling process used visit https://www.icpsr.umich.edu/icpsrweb/ICPSR/studies/36664.
}

indicating that on average people were fairly satisfied with the lives they lead. ${ }^{6}$ Women represented 53 per cent of our sample and the average age was just over 49 years.

\subsection{Dependent Variable}

Life satisfaction in the survey is captured by the question "On the whole, are you satisfied, fairly satisfied, not very satisfied or not at all satisfied with the life your lead?". We recode the variable so satisfied has a score of 4 , fairly satisfied a score of 3 , not very satisfied a score of 2 and not at all satisfied a score of 1 . This means that any estimated coefficients that are positive are correlated with higher life satisfaction and estimated coefficients that are negative, with lower life satisfaction.

\subsection{Individual Level Variables}

\subsubsection{Main Variable of Interest: Fear of Robots}

There are several questions in the survey that relate to perceptions of robots. The first is a general question on how the person views robots which has four possible responses, "Generally speaking, do you have a very positive, fairly positive, fairly negative or very negative view of robots?". There are then a series of questions in which people are asked "To what extent they agree or disagree with whether (1) robots are a good thing for society, because they help people (2) robots steal peoples' jobs and (3) robots are necessary as they can do jobs that are too hard or too dangerous for people. There are four possible responses to these three questions. All people in the survey will answer these questions, but others in the survey are related more to people who are currently employed. In light of this we use just one other question from the survey which asks how people would feel about having a robot to assist you at work. People who are employed, unemployed, students and retired can answer this question. It could be argued that the unemployed and the retired should not answer this question because they do not have an informed view of perhaps how robots can assist in the workplace. However we have no information on how long someone has been unemployed or the reason for being unemployed and to assume this category of people are less informed seems too strict. Retired people are also entitled to an opinion about what they think it would be like to have assistance from a robot drawing on their own work experiences.

The five questions are used to form an average fear of robot variable. Some recoding of the original data was required, notably regarding the question on how people felt about having a robot assist them at work. This question had 10 possible categories instead of the four categories in the other five ques-

\footnotetext{
$\overline{6}$ We simply recoded using recode $\mathrm{LS} 4=13=22=31=4$ in STATA.
} 
tions used. Having looked at the distribution of responses to the question we recoded into four categories where 1 represents people who are very or totally comfortable with robots assisting in the workplace (8, 9 and 10), 2 less comfortable (6 and 7), 3 fairly uncomfortable (4 and 5) and 4 representing those who are very or totally uncomfortable with robots assisting in the workplace (1,2 and 3). Table 1 reveals these five variables have similar factor loadings. When we run a Kaiser-Meyer-Olkin (KMO) measure of sampling adequacy we see that these are all well above 0.7 so are fine to use for factor analysis or principal components analysis. ${ }^{7}$ Given these findings, we also create a fear of robot measure based on principal components analysis and use this as an alternative to the average fear of robot measure in the forthcoming analysis.

It is important to note that as well as fear of robots causing life satisfaction that causality can run in the other direction as well; people who are fearful of robots may well hold these views because of low life satisfaction. In the life satisfaction literature the issue of causality is hard to overcome when using individual, cross sectional data since it is hard to find an instrument that passes the necessary tests. One approach is to control for within sample averages at a regional or some other geographic level but these can be criticised since individuals can both cause and be influenced by their immediate surroundings especially with respect to attitudes and perceptions that they hold. Alternatively using information on the characteristics of parents or using data that has a time-series element to it can result in appropriate instruments. The Eurobarometer survey used in this paper has no such information and we interpret coefficients as correlations, given all other variables in the model remain constant.

\subsubsection{Individual Control Variables}

From the extensive empirical literature on life satisfaction we firstly include two demographic factors; gender and age. Women tend to report significantly higher life satisfaction relative to men consistent with much empirical work (e.g. $[35,40,62,63])$ but a universal explanation for this common empirical finding has not been agreed. Possible explanations focus on the hypothesis that life satisfaction expectations of men are far greater than actual life satisfaction when compared to women which results in men being less satisfied with life. ${ }^{8}$ Following previous work we test for a non-linear rela-

\footnotetext{
7 A score of below 0.5 is given a label of unacceptable, a score between 0.5 and 0.6 is miserable, a score between 0.6 and 0.7 is mediocre, a score between 0.7 and 0.8 is middling, a score between 0.8 and 0.9 is meritorious and a score between 0.9 and 1.0 is marvellous [45].

8 A similar argument has been put forward to explain the finding that women report higher job satisfaction than men [14] although Green et al. [39] find that, overtime, women's job expectations in Britain rise and this gender gap vanishes.
}

Table 1 Items, Factor Loadings and KMO measure for fear of robots

\begin{tabular}{|c|c|c|}
\hline Question & Factor loading & KMO measure \\
\hline $\begin{array}{l}\text { "To what extent do you agree or } \\
\text { disagree with whether robots are } \\
\text { a good thing for society? } \\
(1=\text { totally agree, } 2=\text { tend to } \\
\text { agree, } 3 \text {-tend to disagree, } 4= \\
\text { totally disagree) }\end{array}$ & 0.722 & 0.755 \\
\hline $\begin{array}{l}\text { "To what extent do you agree or } \\
\text { disagree with whether robots } \\
\text { steal peoples' jobs?" } \\
(1=\text { totally disagree, } 2=\text { tend to } \\
\text { disagree, } 3 \text {-tend to agree, } 4= \\
\text { totally agree })\end{array}$ & 0.405 & 0.796 \\
\hline $\begin{array}{l}\text { "To what extent do you agree or } \\
\text { disagree with whether robots are } \\
\text { necessary as they can do jobs } \\
\text { that are too hard or too } \\
\text { dangerous for people?" } \\
(1=\text { totally agree, } 2=\text { tend to } \\
\text { agree, } 3 \text {-tend to disagree, } 4= \\
\text { totally disagree) }\end{array}$ & 0.616 & 0.775 \\
\hline $\begin{array}{l}\text { Generally speaking, do you have a } \\
\text { very positive, fairly positive, } \\
\text { fairly negative or very negative } \\
\text { view of robots?" } \\
(1=\text { very positive, } 2=\text { fairly } \\
\text { positive, } 3=\text { fairly negative, } 4 \\
=\text { very negative) }\end{array}$ & 0.725 & 0.775 \\
\hline $\begin{array}{l}\text { How would you personally feel } \\
\text { about having a robot assist you } \\
\text { at } \\
\text { work (e.g. in manufacturing) } \\
\text { ( } 1=\text { totally comfortable, } 2= \\
\text { fairly comfortable, } 3=\text { fairly } \\
\text { uncomfortable, } 4=\text { totally } \\
\text { uncomfortable) }\end{array}$ & 0.596 & 0.837 \\
\hline Cronbach's Alpha & 0.742 & \\
\hline
\end{tabular}

tionship between age and life satisfaction by including both an age and an age-squared variable. We expect life satisfaction to decline with age but reach a minimum point and then begin increasing. Possible explanations for this include individuals learning to adapt to their own reality in mid-life and re-align aspirations and expectations accordingly, or greater comparison with others as we age [8].

A universal finding in the individual-level life satisfaction literature is that life satisfaction increases with income (e.g. [33, 41, 47, 49]). We do not have information on personal or household income levels in our data. Instead we use selfreported information on whether someone has been fine in paying bills at the end of the month in the past year to form a dummy variable $(1=$ fine to have paid bills, $0=$ from time to time or most of the time have not been able to pay monthly bills) and whether the person sees themselves or their household as belonging to the working class, lower middle class, middle class, upper middle class or upper class of society. 
Whilst class is more complex than income, we expect that life satisfaction increases with movement up the class ladder and include class as a single variable that takes a value of 1-5 for the five different classes. The economic activity of people is included as a group of dummy variables for whether the person is self-employed, a manager, another white collar worker, a manual worker, at home, unemployed or retired. We expect that people who are unemployed report significantly lower life satisfaction than people from any of the other categories, ceteris paribus, consistent with a negative scarring effect of being unemployed [9, 35, 62]. Marital status is also included in a group of dummy variables (cohabit, single, married, divorced, widowed or other marital status). Generally it is found that those who are married report higher levels of life satisfaction than all other categories.

Education is captured by information contained in the question "How old were you when you stopped full-time education?", with higher scores assumed to be associated with higher levels of investment in education. We create three education dummy variables. The first for those who had no full time education or had up to 15 years of education; the second for those who had 16-19 years of education; and thirdly for those who had 20 years or more full time education. Previous research into the impact of education on life satisfaction is mixed. Some studies find that the more educated have higher life satisfaction (e.g., $[9,23,28,38]$ while others find the opposite (e.g., [29, 56]. That there is no universal finding with respect to a relationship between life satisfaction and education is unsurprising. Education is a determinant of income, employment status and marital status, which we control for in our model. There will thus be both an indirect impact on life satisfaction through these variables and a direct impact on life satisfaction. ${ }^{9}$ Finally we include a dummy variable for whether someone lives in a large town $(=1)$ or lives in a small or middle sized town or a rural area or village $(=0)$. Previous work tends to find people who live in large towns or cities report significantly lower life satisfaction when compared to people who live in rural and less populated areas (e.g. [42, 58], with possible explanations for this being that people prefer living in rural areas but have to move to urban areas for work or there are mental health benefits from living closer to nature. ${ }^{10}$

Because of the possibility that people who are fearful of robots may be fearful or negative about many others things, or maybe this way inclined we also control for individual attitudes towards whether people think their country is head-

\footnotetext{
$\overline{9}$ See work by Powdthavee et al [57] who estimate both direct and indirect effects of education on life satisfaction.

10 That nature may have positive mental health benefits draws on the environmental psychology literature. Examples include Van den Berg et al [62], Hartig et al [44], Stigsdotter et al [59], Korpela and Kinnunen [47].
}

ing in the right or wrong direction and whether they think the EU is heading in the right or wrong direction. We also create three dummy variables for whether people have a positive, neutral or negative image of the EU. The inclusion of these variables could reduce any correlation between fear of robots and life satisfaction and may reflect the possibility that fear of robots is part of a fear of many other things.

\subsection{Country Effects}

In order to capture life satisfaction differences between countries we include a group of country dummy variables for each of the 28 countries in the survey. The survey also has information on someone's nationality but we have not included this in our models since the paper's main focus is not on whether someone has migrated or not or on the impact identity has on life satisfaction.

\subsection{Estimation Strategy}

Normally in the life satisfaction literature estimates of life satisfaction are performed using either ordered probit or ordered logit models. However the work of Ferrer-iCarbonell and Frijters [26] and Ferrer-i-Carbonell and Ramos [27] highlighted that such non-linear models and ordinary least squares (OLS) produced qualitatively similar results, but OLS has the advantage of being easier to interpret. The complete model we estimate regresses individual life satisfaction of individual i from country $\mathrm{j}\left(L S_{i, j}\right)$ onto the average fear of robots $\left(\overline{\text { Fearof Robots }}_{i, j}\right)$ variable, other individuallevel controls, $\mathrm{X}$ and country dummies (Country),

$$
L S_{i, j}=\beta_{1} \overline{\text { Fearof Robots }}_{i, j}+\beta_{k} X_{i, j}+\beta_{j} \text { Countr }_{i, j}+\varepsilon_{i, j}
$$

We expect fear of robots to be associated with lower life satisfaction, meaning that $\beta_{1}<0$.

\section{Results}

We begin with a simple regression that controls just for the average fear of robots (Model 1) in Table 2. We see that fear of robots is negatively and significantly correlated with selfreported life satisfaction. A one-point increase in the average fear of robots will result in a decline in life satisfaction of 0.2 points. When we include individual characteristics, we see that the size of the coefficient on fear of robots declines slightly (Model 2), and again when country dummies are included (Model 3). However, the sign and significance of the fear of robot variables do not change. Finally Model 4 controls for the individual's views on whether their country and the EU is going in the wrong direction and whether they have a positive or negative view of the EU. All of these vari- 
Table 2 Life satisfaction and average fear of robots

\begin{tabular}{|c|c|c|c|c|}
\hline Variables & $\begin{array}{l}(1) \\
\text { LS }\end{array}$ & $\begin{array}{l}(2) \\
\text { LS }\end{array}$ & $\begin{array}{l}(3) \\
\text { LS }\end{array}$ & $\begin{array}{l}(4) \\
\text { LS }\end{array}$ \\
\hline \multicolumn{5}{|c|}{$\begin{array}{l}\text { Dependent variable: life satisfaction }(1=\text { not at all satisfied; } 2=\text { not very satisfied; } 3= \\
\text { Fairly satisfied; } 4=\text { very satisfied })\end{array}$} \\
\hline Fear of Robots & $-0.216^{* * *}$ & $-0.087 * * *$ & $-0.064 * * *$ & $-0.036 * * *$ \\
\hline Up to 15 years of education & & -0.018 & $-0.033 * *$ & -0.023 \\
\hline 20 years or more education & & $0.084 * * *$ & $0.024 * *$ & 0.013 \\
\hline Self Employed & & 0.006 & $0.050 * *$ & $0.045 * *$ \\
\hline Manager & & $0.043 * *$ & $0.033^{*}$ & 0.025 \\
\hline Other white collar employee & & 0.004 & 0.013 & 0.011 \\
\hline At home & & 0.001 & -0.033 & -0.031 \\
\hline Unemployed & & $-0.247 * * *$ & $-0.253 * * *$ & $-0.240 * * *$ \\
\hline Retired & & $-0.052 * * *$ & $-0.032 *$ & $-0.028 *$ \\
\hline Student & & $0.086^{* * *}$ & $0.058 * *$ & $0.051 * *$ \\
\hline Female & & $0.029 * * *$ & $0.038 * * *$ & $0.035 * * *$ \\
\hline Age & & $-0.021 * * *$ & $-0.022 * * *$ & $-0.021 * * *$ \\
\hline Age-squared & & $0.000 * * *$ & $0.000 * * *$ & $0.000 * * *$ \\
\hline Social Class & & $0.114 * * *$ & $0.112 * * *$ & $0.103 * * *$ \\
\hline Fine to have paid bills & & $0.488 * * *$ & $0.353 * * *$ & $0.339 * * *$ \\
\hline Cohabit & & -0.013 & $-0.072 * * *$ & $-0.066^{* * *}$ \\
\hline Single & & $-0.095 * * *$ & $-0.158 * * *$ & $-0.153 * * *$ \\
\hline Divorced & & $-0.159 * * *$ & $-0.205^{* * *}$ & $-0.197 * * *$ \\
\hline Widow & & $-0.176^{* * *}$ & $-0.165^{* * *}$ & $-0.162 * * *$ \\
\hline Other marital status & & 0.025 & -0.055 & -0.058 \\
\hline Urban & & $-0.021 * *$ & $-0.018^{*}$ & $-0.019 *$ \\
\hline Things wrong with own country & & & & $-0.085^{* * *}$ \\
\hline Things wrong with the EU & & & & $-0.025 * *$ \\
\hline Positive view of EU & & & & $0.088 * * *$ \\
\hline Negative view of EU & & & & $-0.083 * * *$ \\
\hline Country Dummies & No & No & Yes & Yes \\
\hline Constant & $3.489 * * *$ & $3.114 * * *$ & $3.215^{* * *}$ & $3.267 * * *$ \\
\hline Observations & 19,741 & 19,741 & 19,741 & 19,741 \\
\hline R-squared & 0.036 & 0.235 & 0.333 & 0.341 \\
\hline F-Statistic & 747.7 & 289.1 & 196.9 & 193.5 \\
\hline
\end{tabular}

Reference groups are 16-19 years of education, manual employee, male, not fine to have paid the bills, married and living in a rural area or small town. The country reference group is Croatia Significance levels $* * * p<0.01, * * p<0.05, * p<0.1$ ables are as expected with negative views being associated with lower life satisfaction whilst holding a positive image of the EU is associated with higher life satisfaction. Their inclusion reduces the size of the fear of robots variable indicating that negative views on other things in life are correlated with a specific fear of robots. When we use the principal components measure of fear of robots in Table 3, the results are similar although the size of the coefficient on the fear of robot measure is smaller in each of the models.

The individual controls themselves confirm previous research into correlates of life satisfaction. Life satisfaction has a U-shaped relationship with age. Women report significantly higher life satisfaction than men. There is strong evidence too that life satisfaction increases with the level of education someone has. Those with 20 years of more education report significantly higher life satisfaction levels relative to those with 16-19 years of full time education. The unemployed are the least satisfied with life compared to manual workers, whilst those in better quality jobs report higher levels of life satisfaction. People who are married (the reference group) report significantly higher life satisfaction levels than people who co-habit, are single, divorced, widowed or have another relationship status. People who report being in a higher social class or people who had no problems paying bills in the last month both report higher life satisfaction, conforming to a priories. Residing in a small or large town 
Table 3 Life satisfaction and fear of robots (PCA)

\begin{tabular}{|c|c|c|c|c|}
\hline Variables & $\begin{array}{l}\text { (1) } \\
\text { LS }\end{array}$ & $\begin{array}{l}\text { (2) } \\
\text { LS }\end{array}$ & $\begin{array}{l}\text { (3) } \\
\text { LS }\end{array}$ & $\begin{array}{l}\text { (4) } \\
\text { LS }\end{array}$ \\
\hline \multicolumn{5}{|c|}{ Dependent variable: life satisfaction } \\
\hline PCA Fear of Robots & $-0.087 * * *$ & $-0.035^{* * *}$ & $-0.027 * * *$ & $-0.021 * * *$ \\
\hline Up to 15 years of education & & -0.018 & $-0.033 * *$ & -0.023 \\
\hline 20 years or more education & & $0.084 * * *$ & $0.024 * *$ & 0.013 \\
\hline Self Employed & & 0.007 & $0.050 * *$ & $0.045^{* *}$ \\
\hline Manager & & $0.044 * *$ & $0.033 *$ & 0.025 \\
\hline Other white collar employee & & 0.004 & 0.013 & 0.011 \\
\hline At home & & 0.001 & -0.033 & -0.031 \\
\hline Unemployed & & $-0.247 * * *$ & $-0.253 * * *$ & $-0.240 * * *$ \\
\hline Retired & & $-0.051 * * *$ & $-0.031 *$ & $-0.028 *$ \\
\hline Student & & $0.087 * * *$ & $0.058 * *$ & $0.050 * *$ \\
\hline Female & & $0.029 * * *$ & $0.038 * * *$ & $0.035 * * *$ \\
\hline Age & & $-0.021 * * *$ & $-0.022 * * *$ & $-0.021 * * *$ \\
\hline Age-squared & & $0.000 * * *$ & $0.000 * * *$ & $0.000 * * *$ \\
\hline Social Class & & $0.114 * * *$ & $0.112 * * *$ & $0.103 * * *$ \\
\hline Fine to have paid bills & & $0.488 * * *$ & $0.352 * * *$ & $0.338 * * *$ \\
\hline Cohabit & & -0.013 & $-0.072 * * *$ & $-0.066^{* * *}$ \\
\hline Single & & $-0.094 * * *$ & $-0.158 * * *$ & $-0.153 * * *$ \\
\hline Divorced & & $-0.159 * * *$ & $-0.205^{* * *}$ & $-0.197 * * *$ \\
\hline Widow & & $-0.175^{* * *}$ & $-0.164 * * *$ & $-0.162 * * *$ \\
\hline Other marital status & & 0.025 & -0.055 & -0.058 \\
\hline Urban & & $-0.021 * *$ & $-0.017 *$ & $-0.019 *$ \\
\hline Things wrong with own country & & & & $-0.085^{* * *}$ \\
\hline Things wrong with the EU & & & & $-0.025^{* *}$ \\
\hline Positive view of EU & & & & $0.088 * * *$ \\
\hline Negative view of EU & & & & $-0.083^{* * *}$ \\
\hline Country Dummies & No & No & Yes & Yes \\
\hline Constant & $3.013 * * *$ & $2.920 * * *$ & $3.073 * * *$ & $3.108 * * *$ \\
\hline Observations & 19,741 & 19,741 & 19,741 & 19,741 \\
\hline R-squared & 0.035 & 0.235 & 0.334 & 0.347 \\
\hline $\mathrm{F}$ & 725.8 & 288.9 & 197.1 & 193.7 \\
\hline
\end{tabular}

Reference groups are 16-19 years of education, manual employee, male, not fine to have paid the bills, married and living in a rural area or small town. The country reference group is Croatia Significance levels $* * * p<0.01, * * p<0.05, * p<0.1$ compared to living in a rural area has no statistical impact on life satisfaction. Finally, individuals who hold negative views of where their country is going and where the EU is going report significantly lower levels of life satisfaction, whilst people with a positive image of the EU report significantly higher levels of life satisfaction.

These findings suggest that people's fears of robots are correlated with their life satisfaction. In order to understand better whether this fear of robots is driven by particular groups of people we estimated models for just the employed. This group of people may be expected to be more fearful of robots with respect to their employment today and tomorrow and so the negative correlation with life satisfaction would be larger. The results in Table 4 illustrate a negative and significant correlation between fear of robots and life satisfaction with the size of the correlation slightly smaller if compared to the results in Tables 2 and 3. In Table 5 we analyse the relationship between fear of robots and life satisfaction for different age groups. All of the models illustrate a negative correlation between fear of robots and life satisfaction but this relationship is significant only for those aged between 31 and 40, 41 and 50 and those above 60 years of age. In terms of magnitude those between 41 and 50 years of age report the largest negative correlation with life satisfaction. This suggests that more experienced workers are more fearful of robots than those aged between 15 and 30 years. 
Table 4 Life satisfaction of workers

\begin{tabular}{|c|c|c|}
\hline Variables & $\begin{array}{l}\text { (1) } \\
\text { LS }\end{array}$ & $\begin{array}{l}\text { (2) } \\
\text { LS }\end{array}$ \\
\hline \multicolumn{3}{|c|}{ Dependent variable: life satisfaction } \\
\hline Fear of robots & $-0.038 * * *$ & \\
\hline PCA Fear of robots & & $-0.016^{* * *}$ \\
\hline Up to 15 years of education & $-0.046^{*}$ & $-0.046^{*}$ \\
\hline 20 years or more education & 0.011 & 0.011 \\
\hline Self Employed & $0.056^{* * *}$ & $0.056 * * *$ \\
\hline Manager & $0.045 * *$ & $0.045 * *$ \\
\hline Other white collar employee & 0.022 & 0.022 \\
\hline Female & 0.011 & 0.011 \\
\hline Age & $-0.019 * * *$ & $-0.019 * * *$ \\
\hline Age-squared & $0.000 * * *$ & $0.000 * * *$ \\
\hline Social Class & $0.097 * * *$ & $0.097 * * *$ \\
\hline Fine to have paid bills & $0.318 * * *$ & $0.318 * * *$ \\
\hline Cohabit & $-0.053 * * *$ & $-0.053 * * *$ \\
\hline Single & $-0.146 * * *$ & $-0.146^{* * *}$ \\
\hline Divorced & $-0.172 * * *$ & $-0.172 * * *$ \\
\hline Widow & $-0.201 * * *$ & $-0.201 * * *$ \\
\hline Other marital status & -0.132 & -0.133 \\
\hline Urban & -0.020 & -0.020 \\
\hline Things wrong with own country & $-0.097 * * *$ & $-0.097 * * *$ \\
\hline Things wrong with the EU & -0.006 & -0.006 \\
\hline Positive view of EU & $0.084 * * *$ & $0.084 * * *$ \\
\hline Negative view of EU & $-0.074 * * *$ & $-0.074 * * *$ \\
\hline Country dummies & Yes & Yes \\
\hline Constant & $3.116^{* * *}$ & $3.061 * * *$ \\
\hline Observations & 9.571 & 9.571 \\
\hline R-squared & 0.323 & 0.323 \\
\hline $\mathrm{F}$ & 90.64 & 90.67 \\
\hline
\end{tabular}

Reference groups are 16-19 years of education, manual employee, male, not fine to have paid the bills, married and living in a rural area or small town. The country reference group is Croatia

Significance levels $* * * p<0.01, * * p<0.05, * p<0.1$

\section{Robustness Checks}

Whilst including country dummies in our regressions is a way of controlling for between country differences and their impact on life satisfaction, this fails to differentiate between country-level and individual-level components and how they correlate with life satisfaction. It is also possible that individuals' fears of robots are correlated with the macro-economic environment and institutions of a country, as found by Dekker et al. [20] and acts as a robustness test to our previous findings. We use a linear multi-level regression model that recognizes that the macro-economic environment and institutions of a country may impact on the life satisfaction of individuals and may correlate with people's fears of robots. The regression informs the researcher of how much of the variance in individual life satisfaction is due to country-level and individual-level components. We include two countrylevel macro-economic variables, GDP per capita and the unemployment rate. We also include the trade union density of each country since this may reflect the power of workers in a country to voice their concerns about a range of issues including job insecurity, earnings and work conditions. Finally we include a variable for average job strain in a country, calculated by the OECD, that measures the quality of the work environment. Unfortunately, some of these variables are not available for Northern Ireland, Cyprus, Malta, Bulgaria, Romania and Croatia so our sample size is smaller than previously.

The results of the multi-level analysis are reported in Table 6. All models include a random intercept at the country level. Model 1 reports that $19.2 \%$ of the total variation in individual level life satisfaction is due to cross-country differences $((0.102 /(0.433+0.102))=19.1 \%)$ meaning a multi-level approach is appropriate. Model 2 includes individual level controls which are all similar sizes and significance levels to those reported in the OLS regression in Table 2. When country-level variables are included in Model 3 , we see that people living in countries with high levels of job strain report significantly lower levels of life satisfaction, with all other macro-economic variables insignificant. The estimation of these models has no impact on either the size or significance of the fear of robot coefficient. For a comparison Model 4 represents the equivalent OLS regression which includes country dummies. The coefficient on fear of robots remains similar to that in Model 3.

The forced exclusion of some countries from Table 6 is not ideal but the slightly larger correlation between fear of robots and life satisfaction in this sample leads us to think that estimating the model for old and new EU country members may reveal some difference in this correlation through peoples' views of the EU and the performance of their own country. We grouped together the founding countries of the EU union with those that joined in 1973. We then grouped Greece, Spain and Portugal together since they joined in the 1980s. Austria, Finland and Sweden were grouped as they all joined in 1995 . The final group represent former communist party countries who joined in 2004 and 2007. Table 7 shows that fear of robots is significant amongst older member countries; amongst Austria, Finland and Sweden and amongst former communist countries who joined the EU in the 2000s. When we run the same analysis but remove the four variables on image of the EU and how the EU and how the country is performing we see a clearer relationship. Table 7 shows that the fear of robot coefficient doubles in size for people from Greece, Spain and Portugal (Column 4) and for people from former communist countries (Column 8) when we do not control for views on EU and country performance. The coefficient increases by approximately a half for people from 
Table 5 Life satisfaction by age group

\begin{tabular}{|c|c|c|c|c|c|}
\hline Variables & $\begin{array}{l}\text { (1) } \\
\text { Age }<30\end{array}$ & $\begin{array}{l}(2) \\
30-39\end{array}$ & $\begin{array}{l}(3) \\
40-49\end{array}$ & $\begin{array}{l}\text { (4) } \\
50-59\end{array}$ & $\begin{array}{l}(5) \\
60+\end{array}$ \\
\hline \multicolumn{6}{|l|}{ Dependent variable: life satisfaction } \\
\hline Fear of robots & -0.003 & $-0.037 *$ & $-0.046^{* *}$ & -0.019 & $-0.038 * * *$ \\
\hline Up to 15 years of education & -0.100 & -0.055 & -0.027 & -0.039 & -0.000 \\
\hline 20 years or more education & 0.013 & 0.010 & 0.023 & 0.007 & 0.013 \\
\hline Self Employed & 0.023 & $0.089 * *$ & 0.052 & 0.034 & -0.015 \\
\hline Manager & 0.064 & 0.041 & 0.015 & 0.025 & -0.017 \\
\hline Other white collar employee & -0.050 & 0.040 & 0.027 & -0.009 & -0.020 \\
\hline At home & $-0.110^{*}$ & -0.014 & -0.074 & -0.049 & 0.008 \\
\hline Unemployed & $-0.229 * * *$ & $-0.196 * * *$ & $-0.269 * * *$ & $-0.310 * * *$ & $-0.139 * *$ \\
\hline Retired & & $-0.159^{*}$ & $-0.122 * *$ & $-0.140 * * *$ & -0.016 \\
\hline Student & $0.105 * * *$ & $0.298 * * *$ & -0.113 & 0.081 & -0.262 \\
\hline Female & 0.021 & $0.072 * * *$ & 0.005 & $0.050 * *$ & $0.031^{*}$ \\
\hline Social class & $0.086 * * *$ & $0.127 * * *$ & $0.109 * * *$ & $0.100 * * *$ & $0.089 * * *$ \\
\hline Fine to have paid bills & $0.245 * * *$ & $0.330 * * *$ & $0.328 * * *$ & $0.386 * * *$ & $0.360 * * *$ \\
\hline Cohabit & $-0.079 * *$ & -0.022 & $-0.064 *$ & $-0.109 * * *$ & $-0.074 *$ \\
\hline Single & $-0.121 * * *$ & $-0.158 * * *$ & $-0.198 * * *$ & $-0.150 * * *$ & $-0.159 * * *$ \\
\hline Divorced & $-0.297 * * *$ & $-0.372 * * *$ & $-0.219 * * *$ & $-0.167 * * *$ & $-0.135^{* * *}$ \\
\hline Widow & -0.097 & $-0.476^{* * *}$ & $-0.441 * * *$ & $-0.173 * * *$ & $-0.123^{* * *}$ \\
\hline Other marital status & 0.013 & -0.318 & -0.137 & -0.132 & -0.284 \\
\hline Urban & $-0.065^{* *}$ & -0.013 & 0.004 & $-0.043^{*}$ & -0.000 \\
\hline Things wrong with own country & -0.047 & $-0.091 * * *$ & $-0.121 * * *$ & $-0.083 * * *$ & $-0.073^{* * *}$ \\
\hline Things wrong with the EU & $-0.055^{*}$ & 0.010 & 0.005 & -0.031 & $-0.037 *$ \\
\hline Positive view of EU & $0.120 * * *$ & $0.066 * * *$ & $0.064 * * *$ & $0.079 * * *$ & $0.102 * * *$ \\
\hline Negative view of EU & $-0.104 * * *$ & -0.016 & $-0.148 * * *$ & $-0.079 * *$ & $-0.073 * * *$ \\
\hline Country dummies & Yes & Yes & Yes & Yes & Yes \\
\hline Constant & $2.805 * * *$ & $2.589 * * *$ & $2.689 * * *$ & $2.544 * * *$ & $2.730 * * *$ \\
\hline Observations & 3.071 & 3.075 & 3.438 & 3.447 & 6.710 \\
\hline R-squared & 0.251 & 0.336 & 0.389 & 0.383 & 0.376 \\
\hline $\mathrm{F}$ & 19.87 & 29.41 & 41.51 & 40.59 & 76.99 \\
\hline
\end{tabular}

Reference groups are 16-19 years of education, manual employee, male, not fine to have paid the bills, married and living in a rural area or small town. The country reference group is Croatia Significance levels $* * * p<0.01, * * p<0.05, * p<0.1$ countries who founded the EU and who joined in 1973 (Column 3) and for people from Austria, Finland and Sweden (Column 6).

\section{Discussion}

Technological change transforms the economic landscape and consequently peoples' lives. Whether this is necessarily for the better has and will continue to be disputed. Much recent research has forecast that robots and next-generation robots will have a negative impact on earnings and employment of certain types of workers. This paper asks a different but no less important question: whether people's fear of robots is associated with life satisfaction. By using a data set with questions that asked about peoples' views on robots we found that a fear of robots does significantly correlate with a lower life satisfaction for a number of different model specifications. People who are employed or unemployed and have a fear of robots also report lower life satisfaction but the size of this impact is smaller compared to when we include students, people who work at home and people who are retired in the analysis. This may reflect workers being more open to working with robots and alongside robots or having adapted to working with and alongside robots. There is, as yet, little work that asks whether worker attitudes towards robots and new technologies impacts on their own life or job satisfaction. Brougham and Haar [11] is one of the few studies to do so with more than a handful of employees. They find evidence that new technologies (defined as smart technology, artificial intelligence, robotics, and algorithms) are associ- 
Table 6 Life satisfaction (multi-level regression)

\begin{tabular}{|c|c|c|c|c|}
\hline Variables & $\begin{array}{l}\text { (1) } \\
\text { LS }\end{array}$ & $\begin{array}{l}\text { (2) } \\
\text { LS }\end{array}$ & $\begin{array}{l}\text { (3) } \\
\text { LS }\end{array}$ & $\begin{array}{l}\text { (4) } \\
\text { LS }\end{array}$ \\
\hline \multicolumn{5}{|c|}{ Dependent variable: life satisfaction } \\
\hline Fear of Robots & & $-0.042 * * *$ & $-0.042 * * *$ & $-0.043 * * *$ \\
\hline Up to 15 years of education & & $-0.034 * *$ & $-0.034 * *$ & $-0.035 * *$ \\
\hline 20 years or more education & & 0.003 & 0.002 & 0.003 \\
\hline Self Employed & & 0.032 & 0.033 & 0.033 \\
\hline Manager & & 0.027 & 0.027 & 0.026 \\
\hline Other white collar employee & & 0.002 & 0.003 & 0.003 \\
\hline At home & & -0.007 & -0.007 & -0.009 \\
\hline Unemployed & & $-0.250 * * *$ & $-0.249 * * *$ & $-0.250 * * *$ \\
\hline Retired & & $-0.034 *$ & $-0.034^{*}$ & $-0.034^{*}$ \\
\hline Student & & $0.063 * *$ & $0.062 * *$ & $0.062 * *$ \\
\hline Female & & $0.040 * * *$ & $0.040 * * *$ & $0.040 * * *$ \\
\hline Age & & $-0.019 * * *$ & $-0.019 * * *$ & $-0.019 * * *$ \\
\hline Age-squared & & $0.000 * * *$ & $0.000 * * *$ & $0.000 * * *$ \\
\hline Social Class & & $0.103 * * *$ & $0.103 * * *$ & $0.101 * * *$ \\
\hline Fine to have paid bills & & $0.337 * * *$ & $0.337 * * *$ & $0.337 * * *$ \\
\hline Cohabit & & $-0.060 * * *$ & $-0.060 * * *$ & $-0.060 * * *$ \\
\hline Single & & $-0.144 * * *$ & $-0.144 * * *$ & $-0.143 * * *$ \\
\hline Divorced & & $-0.192 * * *$ & $-0.193 * * *$ & $-0.192 * * *$ \\
\hline Widow & & $-0.160 * * *$ & $-0.161 * * *$ & $-0.160 * * *$ \\
\hline Other marital status & & -0.047 & -0.047 & -0.047 \\
\hline Urban & & $-0.028 * * *$ & $-0.028 * * *$ & $-0.026^{* *}$ \\
\hline Things wrong with own country & & $-0.080 * * *$ & $-0.080 * * *$ & $-0.080 * * *$ \\
\hline Things wrong with the EU & & $-0.026^{* *}$ & $-0.026 * *$ & $-0.026 * *$ \\
\hline Positive view of EU & & $0.094 * * *$ & $0.094 * * *$ & $0.094 * * *$ \\
\hline Negative view of EU & & $-0.074 * * *$ & $-0.074 * * *$ & $-0.074 * * *$ \\
\hline Country dummies & No & No & No & Yes \\
\hline GDP per capita & & & $0.050 *$ & \\
\hline Unemployment rate & & & 0.040 & \\
\hline TU Density & & & 0.053 & \\
\hline Job Strain & & & $-0.156^{* * *}$ & \\
\hline Constant & $3.046^{* * *}$ & $3.237 * * *$ & $3.232 * * *$ & $3.656^{* * *}$ \\
\hline Variance country level & 0.102 & 0.057 & 0.016 & \\
\hline Variance individual level & 0.433 & 0.351 & 0.351 & \\
\hline Observations & 17,018 & 17,018 & 17,018 & 17,018 \\
\hline Number of groups & 23 & 23 & 23 & \\
\hline
\end{tabular}

Reference groups are 16-19 years of education, manual employee, male, not fine to have paid the bills, married and living in a rural area or small town. The country reference group is Croatia

Significance levels $* * * p<0.01, * * p<0.05, * p<0.1$ ated with lower job satisfaction, greater turnover intentions and a higher likelihood of depression amongst workers.

More importantly we found that peoples' views on whether they saw their country and the EU in a positive or negative light correlates with our fear of robot measures. This gives weight to the argument that measuring fear of robots may reflect people's deep rooted fear, or negative and positives views, or optimistic and pessimistic views on a variety of things such as fear of loneliness, fear of unemployment, fear of poor mental and physical health. ${ }^{11}$ When we test across a number of different groups, it is clear that views about the state of one's country or of the EU or of the image of the EU reduce the size of the association of fear of robots on life satisfaction. Noticeably when placing countries into groups

\footnotetext{
${ }^{11}$ Liang and Lee [48] and McClure [51] find evidence for this using data from the USA.
} 


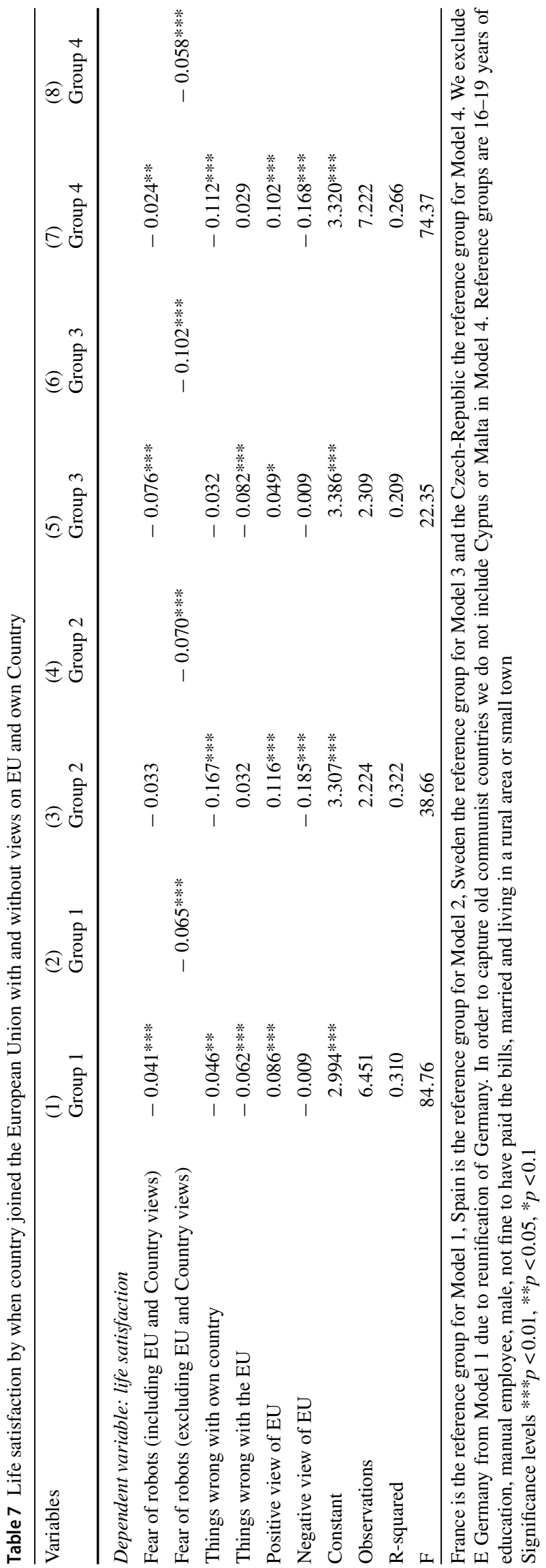

based on how long they have been a member of the EU we find that people from countries who are the oldest members of the EU, and people living in Finland, Sweden or Austria (Group 3) retain the largest and most significant decline in life satisfaction from fear of robots before and after controlling for their views on their own country and the EU. This suggests that amongst people from within these two groups of countries there could well be a greater fear of robots.

\section{Limitations}

The correlation of fear of robots with whether people think the country or the EU is heading in the right direction raises questions as to whether robots are detrimental to life satisfaction or whether this reflects deeper traits of individuals towards being negative or positive, pessimistic or optimistic, trusting or distrusting, or being fearful of anything new in life. This ensures that we interpret the correlations in the paper with a good degree of caution. The psychological nature of fear means that taking into account the individual's personality is important. Penley and Tomaka [55] for example find fear is correlated with four of McCrae and Costa's Big-5 personality dimensions. That these factors are omitted from our analysis means the correlations are likely to be biased upwards in their size. However, these traits are also likely to impact on many of the other individual controls. For example someone's marital status or whether someone is employed or not and in what type of job. This means all of our coefficients are potentially biased. What we can say is that people's attitudes towards robots, whether they are caused by a fear of robots or by the predictable psychological traits of the person or both, can result in robots and other technologies such as artificial intelligence not being wanted by people with this impacting on the current life satisfaction of people.

Another possible bias not considered in this paper is that different countries in our sample have different adoption rates of new technologies. We distinguish between when countries joined the European Union, with this possibly being associated with adoption rates if we argue poorer countries are slower to adopt. However a better measure would be to calculate an "early adopter" index based on evidence of how widespread and integrated technologies are in each country. ${ }^{12}$ The rate of adoption could also be related to the institutional differences between countries and cultural differences between countries. Indeed cultural differences between countries could not just relate to rate of adoption, but to life satisfaction itself, to a fear of robots and to a fear of new things generally. Hofstede's dimensions of culture offers a framework in which to approach this. For example we could estimate country-level measures of uncertainty

12 We thank an anonymous reviewer for this suggestion. 
avoidance (tolerance to unpredictability) that we could reasonably expect to correlate with life satisfaction and with fear of robots. ${ }^{13}$

Causality is also an issue since as well as fear of robots reducing life satisfaction there is also the possibility that someone with a low level of life satisfaction will be more fearful of robots or indeed more fearful of many others things since they are possibly feeling vulnerable. The issue of endogeneity is something that requires repeat cross-sectional data or better still a panel data set that asks questions about people's views about robots and their experiences of using robots as well as their life satisfaction and ideally health satisfaction and mental health satisfaction. Present data sets do not have this level of information meaning we can only ever interpret coefficients as correlations and be aware that there are likely to be correlations between our explanatory variables and any fear of robots measure.

\section{Conclusion}

Technological change is one of the driving forces of capitalism. The latest economic research predicts that the current level of robotic usage or an increased rate of robotic usage will have detrimental effects on both employment and earnings in a variety of occupations and industries in high income countries. Whether these predictions are accurate or not can only be tested over time, but in this paper we find evidence that people who fear robots report significantly lower levels of life satisfaction. While this result is far from conclusive it relates to other findings about workers in particular being fearful of robots replacing them completely or replacing aspects of their job (e.g. [50]). As firms introduce newgeneration robots into the workplace and, more broadly, new technologies associated with I4.0 then they need to include current workers who will be affected by such technologies in this introduction to allay at least some of the fears that they have. Brohol et al. [10] provide recommendations for how humans could become more accepting of robots, based on a human-robot collaboration acceptance model (HRCAM). It is also necessary to highlight to workers the opportunities that could arise within the company as a result of adopting new technologies, notably related to reducing the number of monotonous tasks, to see technologies as helping their own productivity and increasing the number of tasks in the job that require creativity and imagination.

Whilst use of robots and in particular next-generation robots is an integral part of I4.0 and will undoubtedly result in greater efficiencies, greater profits and more economic growth there are bigger questions that roboticists and tech-

\footnotetext{
13 Again we would like to thank an anonymous reviewer for this suggestion.
}

nologists need to be aware of, notably how people will generate enough earnings to live on as more and more tasks in current jobs are performed by robots as well as advanced data communication systems and embedded intelligence [43] and artificial intelligence. The history of previous industrial revolutions tell us that the lives of people changed dramatically during these tumultuous times [51, 52]. History tells us though, that on average, there were long-term benefits to future generations of workers and the population in general in Western economies. There was a notable decline in the average hours worked per week and greater rights for workers. However these were hard won battles that required significant pieces of legislation to catch up with, what was considered at the time, unethical work practices in factories. Presently the governance of emerging science and innovation that includes next-generation robots, roboticists and technologists is a "major challenge to contemporary democracies" [59]. Along with others we call for a more responsible innovation framework that includes all stakeholders in the innovation process to understand where I 4.0 can best be used in national and international interests.

\section{Compliance with ethical standards}

Conflict of interest The authors declare that they have no conflict of interest.

Open Access This article is licensed under a Creative Commons Attribution 4.0 International License, which permits use, sharing, adaptation, distribution and reproduction in any medium or format, as long as you give appropriate credit to the original author(s) and the source, provide a link to the Creative Commons licence, and indicate if changes were made. The images or other third party material in this article are included in the article's Creative Commons licence, unless indicated otherwise in a credit line to the material. If material is not included in the article's Creative Commons licence and your intended use is not permitted by statutory regulation or exceeds the permitted use, you will need to obtain permission directly from the copyright holder. To view a copy of this licence, visit http://creativecomm ons.org/licenses/by/4.0/.

\section{References}

1. Acemoglu D, Restrepo P (2017) "Robots and jobs: evidence from US labor markets. National Bureau of Economic Research Working Paper No. w23285

2. Alexopoulos M, Cohen $J$ (2016) The medium is the measure: technical change and employment, 1909-1949. Rev Econ Stat 98(4):792-810

3. Anelli M, Colantone I, Stanig P (2018) We were the robots: automation and voting behavior in Western Europe. Bocconi University $\{$ Mimeo\}, Milan

4. Autor DH, Levy F, Murnane RJ (2003) The skill content of recent technological change: an empirical exploration. Q J Econ 118(4):1279-1333 
5. Batty M (2015) "Creative destruction, long waves and the age of the smart city. Centre for Advanced Spatial Analysis Working Paper Series No. 200

6. Berryman C, Ferguson C, Negy C (2018) Social media use and mental health among young adults. Psychiatr Q 89(2):3017-3314

7. Bjørnskov C, Dreher A, Fischer JA (2010) Formal institutions and subjective well-being: revisiting the cross-country evidence. Eur J Polit Econ 26:419-430

8. Blanchard D, Oswald A (2008) Is well-being U-shaped over the life cycle? Soc Sci Med 66(8):1733-1749

9. Blanchflower D, Oswald AJ (2004) Well-being over time in Britain and the USA. J Public Econ 88(7):1359-1386

10. Bröhl C, Nelles J, Brandl C, Mertens A, Nitsch V (2019) Human-robot collaboration acceptance model: development and comparison for Germany, Japan, China and the USA. Int J Social Robot 11:709-726

11. Brougham D, Haar J (2018) Smart technology, artificial intelligence, robotics, and algorithms (STARA): employees' perceptions of our future workplace. J Manag Organ 24(2):239-257

12. Brynjolffson E, McAfee A (2014) The second machine age: work, progress, and prosperity in a time of brilliant technologies. W.W. Norton, New York

13. Charles $S$ (2019). Teens, but not adults, suffering mental health disorders linked to social media. [online] NBC News. Available at: https://www.nbcnews.com/health/mental-health/social-medialinked-rise-mental-health-disorders-teens-survey-finds-n982526. Accessed 22 Nov 2019

14. Clark AE (1997) Job satisfaction and gender: why are women so happy at work? Labour Econ 4(4):341-372

15. Clark AE, Oswald AJ (1996) Satisfaction and comparison income. J Public Econ 61:359-381

16. Clark AE, Georgellis Y, Sanfey P (2001) Scarring: the psychological impact of past unemployment. Economica 68(270):221-241

17. Cooper H, Okamura L, Gurka V (1992) Social activity and subjective well-being. Personal Individ Differ 13:573-583

18. Davila J, Hershenberg R, Gorman K, Bhatia V, Starr L (2012) Frequency and quality of social networking among young adults: associations with depressive symptoms, rumination and corumination. Psychol Pop Media Cult 192:72-86

19. Diener E, Seligman MEP (2002) Very happy people. Psychol Sci 13:81-84

20. Dekker F, Salomons A, van der Waal J (2017) "Fear of robots at work: the role of economic self-interest. Socio-Econ Rev 15(3):539-562

21. Demir M, Özdemir M, Weitekamp LA (2007) Looking to happy tomorrows with friends: best and close friendships as they predict happiness. J Happiness Stud 8:243-271

22. Demir M, Weitekamp LA (2007) I am so happy "cause today I found my friend: friendship and personality as predictors of happiness. $\mathbf{J}$ Happiness Stud 8:181-211

23. Easterlin RA (2001) Income and happiness: towards a unified theory. Econ J 111(473):465-484

24. Elsby MWL, Hobijn B, Şahin A (2013) The decline of the U.S. labor share. Brookings papers on economic activity. Brookings Institution Press, Washington, pp 1-63

25. Feldman N, van der Beek K (2014) Skill choice and skill complementarity in eighteenth century england: 1710-1770. SSRN Working Paper Series No. 2417894

26. Ferrer-i-Carbonell A, Frijters P (2004) How important is methodology for the estimates of the determinants of happiness. Econ $\mathbf{J}$ 114(497):641-659

27. Ferrer-i-Carbonell A, Ramos X (2014) Inequality and happiness. J Econ Surv 28(5):1016-1027

28. Ferrer-i-Carbonell A (2005) Income and well-being: an empirical analysis of the comparison income effect. J Public Econ 89(5-6):997-1019
29. Flouri E (2004) "Subjective well-being in midlife: the role of involvement of and closeness to parents in childhood. J Happiness Stud 5(4):335-358

30. Freeman R (2015) Who owns the robots rules the world Workers can benefit from technology that substitutes robots or other machines for their work by owning part of the capital that replaces them. IZA World of Labor Volume 5

31. Frey CB, Osborne MA (2017) The future of employment: how susceptible are jobs to computerisation? Technol Forecast Soc Chang 114:254-280

32. Frey CB, Berger T, Chen C (2017) Political machinery: automation anxiety and the 2016 US presidential election. University of Oxford, Oxford

33. Frijters P, Haisken-DeNew JP, Shields MA (2004) "Money does matter! Evidence from increasing real income and life satisfaction in east germany following reunification. Am Econ Rev 94(3):730-740

34. Gallego A, Kurer T, Scholl N (2018) "Not so disruptive after all: how work- " place digitalization affects political preferences." Unpublished manuscript, Barcelona Institute of International Studies

35. Gerlach K, Stephan G (1996) A paper on unhappiness and unemployment in Germany. Econ Lett 52(3):325-330

36. Goos M, Manning A (2007) Lousy and lovely jobs: the rising polarization of work in Britain. Rev Econ Stat 89(1):118-133

37. Giuntella O, Wang T (2019) "Is an army of robots marching on chinese jobs? IZA Discussion Paper No. 12281

38. Graham C, Pettinato S (2002) Happiness and hardship: opportunity and insecurity in new market economies. Brookings Institution Press, Washington

39. Green CP, Heywood JS, Kler P, Leeves G (2018) Paradox lost: The disappearing female job satisfaction premium. Br J Ind Relat 56(3):484-502

40. Habibov N, Afandi E (2015) Pre- and post-crisis life-satisfaction and social trust in transitional countries: an initial assessment. Soc Indic Res 121(2):503-524

41. Kahneman D, Deaton A (2010) High income improves evaluation of life but not emotional well-being. PNAS 107(38):16489-16493

42. Knight J, Gunatilaka R (2010) The rural-urban divide in China: income but not happiness? J Dev Stud 46:506-534

43. Kumar SV, Khamis A, Fiorini S, Carbonera J, Olivares Alarcos A, Habib M, Goncalves P, Li H, Olszewska J (2019) "Ontologies for industry 4.0. Knowl Eng Rev 34:E17. https://doi.org/10.1017/s02 69888919000109

44. Hudson J, Orviska M, Hunady J (2017) People's attitudes to robots in caring for the elderly. Int J Soc Robot 9:199-210

45. Karabarbounis L, Neiman B (2014) Capital depreciation and labor shares around the world: measurement and implications. Working Paper 20606

46. Kingdon G, Knight JB (2004) Unemployment in South Africa: the nature of the beast. World Dev 32(3):391-408

47. Layard R, Mayraz G, Nickell S (2010) Does relative income matter? Are the critics right? In: Diener DK, John H (eds) International difference in well-being. Oxford University Press, Inc, New York

48. Liang Y, Lee SA (2017) Fear of autonomous robots and artificial intelligence: evidence from national representative data with probability sampling. Int J Soc Robot 9:379-384. https://doi.org/10.10 07/s12369-017-0401-3

49. Luttmer EFP (2005) Neighbors as negatives: relative earnings and well-being. Q J Econ 120(3):963-1002

50. McClure PK (2018) "You're fired", says the robot: the rise of automation in the workplace, technophobes, and fears of unemployment. Soc Sci Comput Rev 36(2):139-156

51. Mokyr J (1992) The lever of riches: technological creativity and economic progress. Oxford University Press Inc., New York 
52. Mokyr J, Vickers C, Ziebarth NL (2015) The history of technological anxiety and the future of economic growth: is this time different? J Econ Perspect 29(3):31-50

53. OECD (2012) OECD employment outlook 2012. OECD, Paris

54. Pénard T, Poussing N, Suire R (2013) Does the internet make people happier? J Socio-Econ 46:105-116

55. Penley J, Tomaka J (2002) Associations among the Big Five, emotional responses, and coping with acute stress. Personal Individ Differ 32(7):1215-1225

56. Powdthavee N (2008) Putting a price tag on friends, relatives, and neighbors: using surveys of life-satisfaction to value social relationships. J Socio-Econ 37(4):1459-1480

57. Rodrıguez-Pose A, Maslauskaite K (2012) Can policy make us happier? Individual characteristics, socio-economic factors and life satisfaction in Central and Eastern Europe. Camb J Reg Econ Soc 5:77-96

58. Sørensen JFL (2014) Rural-urban differences in life satisfaction: evidence from the European Union. Reg Stud 48(9):1451-1466

59. Stilgoe J, Owen R, Macnaghten P (2013) Developing a framework for responsible innovation. Res Policy 42:1568-1580

60. Stutzer A (2004) The role of income inspirations in individual happiness. J Econ Behav Org 54(1):89-109

61. Taipale S, de Luca F, Sarrica M, Fortunati L (2015) Robot shift from industrial production to social reproduction. In: Vincent $\mathrm{J}$, Taipale S, Sapio B, Lugano G, Fortunati L (eds) Social robots from a human perspective. Springer, Berlin, pp 11-24
62. Winkelmann R (2009) Unemployment, social capital and subjective well-being. J Happiness Stud 10(4):412-430

63. Winkelmann L, Winkelmann R (1998) Why are the unemployed so unhappy? Evidence from panel data. Economica 65(257):1-15

Publisher's Note Springer Nature remains neutral with regard to jurisdictional claims in published maps and institutional affiliations.

Tim Hinks achieved his doctorate in Racial Wage Discrimination in post-Apartheid South Africa in 2000 from the University of Hull, UK. He was a post-doctoral student at the University of Middlesex, before working as a Senior Research Lead for two years for an economics NGO in South Africa. He subsequently worked at the University of Witwatersand, RSA where he developed an interest in the economics of happiness. He worked at the University of Bath for 4 years before moving to the University of the West of England as Senior Lecturer in 2011. His current research interests include the impact of AI and Robots on the economic landscape, corruption in ex-communist countries and in the cause and effect of life satisfaction. 